\title{
Representation of The Character Value Of Wisdom, Justice, and Low Self-Esteem in The Tale Entitled Hang Tuah
}

\author{
Tia Pratiwi ${ }^{1}$, Sarwiji Suwandi ${ }^{2}$, Nugraheni Eko Wardhani ${ }^{3}$ \\ \{Pratiwitia95@student.uns.ac.id', sarwijiswan@staff.uns.ac.id², \\ nugraheniekowardani_99@staff.uns.ac.id ${ }^{3}$ \} \\ ${ }^{1,2,3}$ Universitas Sebelas Maret, Surakarta, Indonesia
}

\begin{abstract}
The tale of Hang Tuah is a literary work originating from the Malay land which tells the story of the commander in the kingdom of Malacca. The attitude and personality possessed by Hang Tuah strongly reflect good character values. The purpose of this study is to describe the character values of the main character in the tale of Hang Tuah. The data in this study are in the form of conversations of the main character in the tale of Hang Tuah. This study describes the results of the analysis of character values in the tale of HangTuah based on both behavior and conversation carried out. The data source is the Hang Tuah textbook, a book that supports the theory, and a journal that is relevant to this study. The data analysis technique used in this study is the content analysis technique. The results of this study can be concluded that the character values possessed by the main character in the tale of Hang Tuah include: 1) wisdom, 2) justice, and 3) low self-esteem.
\end{abstract}

Keywords: character value of wisdom, justice, low self-esteem, the tale of Hang Tuah

\section{INTRODUCTION}

Character is a behavior that is currently being applied in learning at school. It has also a duty to shape human character for the better. This is in line with what has been described by the Father of Education, Ki HajarDewantara, who before the Indonesian independence had conveyed the idea of becoming an original for its character education in Indonesia. He also stated that by having a good behavior as well as a good characteristic is done good for kids and adults [1] [2].

Character is also very seriously discussed by Lickona, where he has done a lot of study focus on character value. Lickona then said that character value is a thing that must be formed from the beginning since it has been experienced by the younger generation nowadays to be less good. In this regard, the character value is getting formed better to reaching the Indonesian's mission in 2045, which wants to advance the country, one of which is the character of its younger generation [3], [4], [5]. 
Character is a picture of the personality possessed by humans. The character value is now becoming an important part that is useful to build a better nation, especially for Indonesia. This was once explained in a study conducted by Pane and a study conducted by Feszterova which explained that the character of people nowadays is an important problem that is being discussed throughout the world. The same thing was also explained by Fahmy, who was more specific in saying that in Indonesia it was in accordance with the implementation of the new curriculum, namely the curriculum 2013 which emphasized character education to build students' personalities to having extensive knowledge, skills and strong character [6] - [ 8].

Karim then stated that what had happened to old literary work that exists today began to be abandoned by the younger generation. This reflects the difficulties faced by them who want to read old literature as well as to understand the contents of it. In line with what was conveyed by Karim, Fang also stated that it was the same problem of the tale of Hang Tuah was not preserved, especially in the school. So it is not impossible that the existence of the tale of Hang Tuah will be increasingly abandoned. Contrary to this fact, Fang emphasized how important the old literature is as it can make our worldview wider. [9], [10].

Braginsky also explained that the tale is an old literary work that tells the story of life experienced in the royal era by describing the hero of the commander at that time. One of the most popular stories is the tale of Hang Tuah telling about experiences of the main character, Hang Tuah during the kingdom of Malacca. In Indonesia, this most popular story then published by Kementerian Bahasa Pendidikan Nasional then in 2010 by bot GenootSchap [11], [12].

Hang Tuah has a very distinctive character which is good. Good character implied to the previous study done by some researchers which one of them is Lickona. In this regard, Lickona then classified the good character values into ten components. The ten good character values are: 1) wisdom, 2) justice, 3) courage, 4) self-control, 5) love, 6) positive attitude, 7) hard work, 8 ) integrity, 9) gratitude, and 10) low self-esteem. Based on the above ten values in this study we will explore three character values, such as 1) wisdom, 2) justice, and 3) low self-esteem. The main character in the tale of Hang Tuah is a long, extraordinary personality attitude. All of his behavior, how he speaks the language, is very reflective of these three good character values [13].

The tale of Hang Tuah contains character values in the depiction of the main character namely Hang Tuah who was given the title LaksamanaHang Tuah. By reviving the old literary work, especially for the tale of Hang Tuah, to the younger generation in school, it is true then a real contribution to preserve the existence.

As can be found there are several studies related to the character values, the results explain that characters have a significant role, especially during the learning process at school so that character values must continue to be built in the learning process based on existing material. One of the best materials to implement character values is literary-based learning [14] - [16].

Relevant study on character education has also been carried out by Bogomaz who discussed the strength of character in the West Siberian, which said that character can be related to both social and cultural environments. Then the character values in the story were also conveyed by Fadilah in his analysis discussed the character values in the story of frogs which were to become oxen. Two other studies also did the same to discuss the character in some social-cultural studies [17] - [20].

The use of this story as the main focus is based on several things. First, its story is an interesting as the discussion about old literature work has begun to be forgotten so it will be expected to preserve. Second, old literature work can be used as a source of learning because the main character of the story especially the tale of Hang Tuah has a good personality in accordance with the shape of character values applied to the current learning process. Third, 
there has been no study that discussed the character values contained in the main character of the tale of Hang Tuah, because the previous only discussed the limited intrinsic and extrinsic elements of the story, but no one has done the tale of Hang Tuah which then adjusted to the learning process at this time.

Based on the above description, the conversation carried out by the main character, and the behavior that was reflected in the story was used to choose the focus of the study. This study analyzes the representation of the character values of wisdom, justice, and long self-esteem found in the personality of the main character in the tale of Hang Tuah that has relevance to the character values found in the learning process in high school. The purpose of observing the personality of the main character in the tale of Hang Tuah is to observe and then analyze the character values of Hang Tuah which are then adjusted to the character values are in the school.

\section{METHOD}

This is a descriptive-qualitative study. Qualitative study is the process of conducting a study that is used to understand the various phenomena faced by the subject both presented and described in a descriptive sentence based on scientific research methods. Therefore this method is used to analyze the character values contained in the main character of Hang Tuah based on the main character personality he has [21].

The data analyzed in this study are conducted by conversations between characters, as well as behaviors experienced by the main character of Hang Tuah based on the opinions of other characters. Data collection in this study was carried out by 1) identifying the main character, 2) analyzing the excerpts of stories describing the personality of the main character's behavior, 3 ) concluding the character values in the tale of Hang Tuah based on the results of data analysis. The data sources contained in this study are based on 1) The tale of Hang Tuah bot GenootSchap published in 2010 by Kementerian Nasional Pusat Bahasa Pendidikan [12]; 2) The book to support the theory contained in this study; and 3) journals that are relevant and related to the study. The data analysis technique used in this study is in the form of exposure to three character values, namely: 1) wisdom, 2) justice, and 3) low self-esteem.

\section{RESULT AND DISCUSSION}

Based on the ten character values mentioned by Lickona, then an analysis of three of the ten contained in the tale of Hang Tuah was carried out, namely wisdom, justice, and low selfesteem. The explanation of the three character values is described as follows:

\subsection{The Character Value of Wisdom}

The character value of wisdom according to Lickona is how we treat an action. With the implementation of values, we can see things correctly according to the action so it can determine which ones should be prioritized and which are not. [13]

"Maka Baginda pun terlalu kasih akan Hang Tuah dan Hang Jebat, tetapi di dalam budak-budak empat puluh itu, Hang Tuahlah yang lebih karib pada Baginda, karena ia tertuah dari pada budakbudak yang banyak itu lagi bijaksana barang lakunya". (page 42)

"At that time, the King liked two figures namely Hang Tuah and Hang Jebat. However, the wise behavior of Hang Tuah made him more special according to the King". (page 42) 
Based on the above quotation, we know that among the forty young men who became commander in the Malacca land, the character of Hang Tuah did have a different nature than the others because he was wise so that he was highly valued by the King of Malacca.

"Maka saudagar itu pun memandang kepada bantara Tun Tuah. Maka di dalam hatinya, apa juga asalnya bentara kiri ini, tiada patut dijadikan bentar, hulu balang juga lainnya. Pada penglihatan bentara kiri ini bergelar laksamana juga pada akhirnya, karena orang bijaksana". (page 84).

"And at that time, when the merchants came to the area where Hang Tuah lived, the idea emerged that Hang Tuah was not an ordinary commander. According to them, Hang Tuah is a wise warrior and will later get the title of laksamanabecause of this wisdom". (page 84)

Based on the above quotation, we clearly know that Hang Tuah possessed the character value of wisdom reflected the statements conveyed by traders from the Rivet land who stated that because of his wisdom he would someday be awarded the title of Laksamanafor his attitude.

“..... MakaTunTuah pun tersenyum-senyumkarenaTunTuahitu orang bijaksana, barang ilmu ia tahu, arak itu pun seperti air diminumnya”. (page 139)

"Wazir Agung Gajah Mada who was chatting with Batara in the Majapahit kingdom, saw that Hang Tuah was a wise person because of his treatment so far". (page 139)

Based on the above quotation, we know that the Hang Tuah possessed the character value of wisdom clearly reflected based on the conversation carried out by the Wazir Agung Gajah Mada with Seri Batara.

"Maka Patih Gajah Mada pun bermohonlah kembali menghadap Seri Batara. Maka Titah Seri Batara," Hai Patih Gajah Mada, adapun kulihat Laksamana itu bukan barang-barang orang dan bukan barang-barang hulu baling dengan beraninya dan bijaksananya. Syah dan ia tahu ilmu dan ilmu penjurit dan tahu bermain senjata, jangan dikata lagi; sukar kita mengenai dia."

"And because of the wisdom of Hang Tuah, Gajah Mada begged Seri Batara to give him the title of a laksamana. As according to him at that time, besides being wise, Hang Tuah is also a knowledgeable and one who can play weapons".

Based on the above quotation,we know that the Hang Tuah possessed the character value of wisdom that is taken from the conversation carried out by Wazir Agung Gajah Mada and Seri Batara. This is in line with saying that Hang Tuah is a wise and knowledgeable person and the one who can play weapon.

\subsection{The Character Value of Justice}

Justice according to Lickona is how everyone can be treated properly. Nowadays justice that is truly impartial on one side is very difficult to find. Concerns of the justice existence also related to each other even to the morality decrease [13].

“Maka sembah Tun Tuah, "Daulat tuanku, patik memohonkan ampun dan kurnia, patik lihat terlalu sangatlah hal yang dirasainya. Jika tiada pergi mengail, tiada boleh makan. Itulah pada bicara patik, baik juga pada duli yang dipertuan lepaskan ke benua Keling itu dari pada daripada ditahan serupa itu, karena orang kaya saudagar itu, hendak membawa paduka adinda ini ke benua keling. " (page 88) 
"Seeing the arrival of the king of Rivet at that time to the Hang Tuah region, Hang Tuah asked to return it to the area from which he had come, so that there would be no war between the two regions due to local residents' dislike". (page 88)

Based on the above quotation, we do know that the character value of justice possessed by Hang Tuah as well as is added through the word of Hang Tuah submitted to the Malacca king so that it is better to let the young king be taken to the kingdom area and he continued to become king in Rivet rather than fishing in the state of Malacca. From this discussion so that we can see the character value of justice possessed by Hang Tuah which is illustrated through decisions taken so as not to take sides on one side.

"Maka sahut Hang Tuah, Akan bicara manira, jangankan seperti pakanira itu, tiada akan manira tikam, jikalau penggawa majapahit itu sekali pun manira tikam juga.” (page 146)

"Hang Tuah, who at that time was a judge in one case, would never solve the problem by means of violence but by deliberation". (page 146)

Based on the above quotation, the value of Hang Tuah as a judge for the character of the story was appealed through the action of Hang Tuah who wanted to retaliate to anyone who wanted to stab, even though it was carried out by a Majapahit employee.

"Maka sembah bentara Tun Tuah, "Pada bicara patikakan pekerjaan duli yang dipertuan melepaskan padukan adinda ke benua Kelingini, bukan barang-barang pekerjaan juga. Paduka adinda selaku ini, tiada akan baik di dengar ayahanda di Bukit Seguntang itu. Syah dan apatah nama patik yang tua di Melaka ini" (hal 89)

"and at that time Hang Tuah suggested to the Malacca king to release the Queen of Malay to the Rivet". (page 89)

Based on the above quotation, Hang Tuah as the character with his justice explained that he suggested to the Malacca king to release the Malay Queen into Rivet. According to the above quotations explained, the character value of justice possessed by Hang Tuah was true since both behavior and action were reflected that. This is in line to the other perspective character in this story to say so.

\subsection{The Character Value of Low Self-Esteem}

Low self-esteem is a behavior to understanding both the weaknesses and strengths in us so that we become aware of the imperfections that we have. Low self-esteem becomes the beginning in forming character values in each person since by realizing its weaknesses we can make a change ourselves for the better [13].

"Maka kata Penghulu dengan tersenyum, "Sahaya kenal budak-budak itu, kemarin ia duduk di rumah ibu-bapanya itu. Seorang yang bernama Hang Tuah, sahaya lihat bukan barang-barang lakunya dan sikapnya; perkataannya hulu baling juga; barang yang keluar daripada mulutnya, terlalu manis ia berkata-kata. .... (page 28)

"And when the prince came to see Hang Tuah, he said that Hang Tuah had a good personality from the way he spoke". (page 28) 
Based on the above quotation, the character value of justice possessed by Hang Tuah was reflected on both action and behavior so as on the other perspective character to giving a statement that he was in good personality by having the character value of justice.

"Maka kata Hang Tuah, “Adapun sahaya lima orang ini, sudah hamba diperhamba pula, kemanakah menaruh diri sahaya lagi, melainkan padake bawah duli kadam Datuk laki istri juga. (hal 36)

"At that time, the King of Malacca considered that Hang Tuah deserved the title as General for his excellent behavior". (page 36)

Based on the quotation by the Malacca King, Hang Tuah was fair enough to making him the General at last. According to the explanation from the above quotation, it can be seen that the character value of low self-esteem possessed by Hang Tuah was seen from the behavior and the way he said the words in the story of the tale of Hang Tuah.

This study then supports what was conveyed by Mazmudin in a study entitled "Learning moral values through virtual technology: the development and evaluation of Malaysian virtual folktales - hikayat land" which states that learning Malaysian folklore can improve the learning process, especially for the moral values. In this regard, the tale of Hang Tuah classified as an old Malay literature since Indonesia and Malaysia were countries of Malay [22].

\section{CONCLUSION}

The tale of Hang Tuah is an old literature work that tells the story of a commander from the kingdom of Malacca named Hang Tuah. Hang Tuah has a pretty good personality, behavior, and speech. The data then are getting supported by the depiction of Hang Tuah's character based on the conversation that was made in between the character so as on the statements of other figures who supported the statement. Based on the analysis conducted on the tale of Hang Tuah script, it can be concluded that the character values possessed by the main characters of Hang Tuah were included: 1) wisdom, 2) justice, and 3) low self-esteem. The character value of wisdom illustrates how the character giving a solution to every problem they faced especially to deciding what is a better solution. The character value of justice is reflected in the behavior of Hang Tuah who is always fair in his decisions so that no party dominates. The character value of low self-esteem is reflected when Hang Tuah was titled as a General, he was then never arrogant with that whenever its titled was making him get to know by others.

\section{REFERENCES}

[1] K. H. Dewantara, Asas-asas dan Dasar-dasar Taman Siswa. Yogyakarta: Majlis Luhur Persatuan Taman Siswa, 1964.

[2] K. H. Dewantara, Karya Ki Hajar Dewantara: Bagian Pertama (Pendidikan). Yogyakarta: Majlis Luhur Persatuan Taman Siswa, 1967.

[3] T. Lickona, "The Return Of Character Education," Educ. Leadersh., 1993.

[4] T. Lickona, "The Teacher's Role in Character Education," J. Educ., 2017.

[5] F. Rokhman, M. Hum, A. Syaifudin, and Yuliati, "Character Education for Golden Generation 2045 (National Character Building for Indonesian Golden Years)," Procedia - Soc. Behav. Sci., vol. 141, pp. 1161-1165, 2014.

[6] M. M. Pane and R. Patriana, "The Significance of Environmental Contents in Character Education for Quality of Life," Procedia - Soc. Behav. Sci., vol. 222, pp. 244-252, 2016.

[7] M. Feszterova and K. Jomova, "Character of Innovations in Environmental Education," Procedia - Soc. Behav. Sci., vol. 197, no. February, pp. 1697-1702, 2015. 
[8] R. Fahmy, N. Bachtiar, R. Rahim, and M. Malik, "Measuring Student Perceptions to Personal Characters Building in Education: An Indonesian Case in Implementing New Curriculum in High School," Procedia - Soc. Behav. Sci., vol. 211, pp. 851-858, 2015.

[9] M. Karim, Syair Romantik Melayu Klasik: Menjemput Konvensi merebut Makna. Yogyakarta: Histokultura, 2016.

[10] L. Yock Fang, "8. Historical Literature," in A History of Classical Malay Literature, 2018.

[11] Braginsky, Yang Indah, Berfaedah, dan Kamal : Sejarah Sastra Melayu dalam Abad $7-$ 19. Jakarta: Perpustakaan Nasional, 1998.

[12] B. G. Schap, Hikayat Hang Tuah I. Jakarta: Pusat Bahasa Kementerian Pendidikan Nasional, 2010.

[13] T. Lickona, Character Matters: How to Help Our Children Develop Good Judgment, Integrity and Other Essential Virtues. New York: Simon \& Schuster, 2004.

[14] P. Haryono, S. Sugirin, and A. Widyantoro, "Improving Character-based Reading by Applying PQRST Method to the Students of English Education Study Program," Proc. 2nd Work. Lang. Lit. Soc. Educ., pp. 1-5, 2019.

[15] A. Sudigdo, S. Slamet, R. Winarni, and N. Ekowardani, "The Multiculturalism of Children's Literature: A Study about Children's Poems in Surakarta and Yogyakarta," Proc. 2nd Work. Lang. Lit. Soc. Educ., 2019.

[16] S. Kamal, K. Saddhono, and S. Suyitno, "Cowongan is the Cultural Heritage of Banyumas: Relevance of Rituals as a part of the Value Character Education," Proc. 2nd Work. Lang. Lit. Soc. Educ., 2019.

[17] S. A. Bogomaz, S. A. Litvina, N. V. Kozlova, and I. V. Atamanova, "Culture-specific Subjective Evaluation of Character Strengths,” Procedia - Soc. Behav. Sci., vol. 200, no. October, pp. 92-100, 2015.

[18] F. N. Fadilah and D. Kramadibrata, "Analysis of Suria Characters in Katak Hendak Jadi Lembu Based on Cardinal Virtues," Proc. 2nd Work. Lang. Lit. Soc. Educ., 2019.

[19] K. S. Diputra, I. G. N. Japa, I. M. Suarjana, and K. Yudiana, "Lesson Study for Developing the Pedagogical Competence of Pre-Service Teachers by Integrating Character Values in Thematic Teaching at Elementary Schools," Proc. First Int. Conf. Technol. Educ. Sci., 2019.

[20] K. Dharsana, W. E. Paramartha, and G. N. Sudarsana, "Honest Development Characters Which Are Karma Phala Values," Proc. First Int. Conf. Technol. Educ. Sci., 2019.

[21] L. J. Moleong, "Metodologi Penelitian Kualitatif (Edisi Revisi)," in PT. Remaja Rosda Karya, 2017.

[22] M. Z. Masmuzidin, J. Jiang, and T. Wan, "Learning moral values through virtual technology: The development and evaluation of Malaysian virtual folktales-Hikayat Land," Procedia - Soc. Behav. Sci., vol. 31, no. 2011, pp. 315-322, 2012. 